С.М. Лук’янов, І.Р. Медінець, О.С. Тітов, С.В. Блащук

Харківський національний університет Повітряних Сил ім. I. Кожедуба, Харків

\title{
АНАЛІЗ ПРОБЛЕМНИХ ПИТАНЬ ВИКОРИСТАННЯ МАЛИХ ТАКТИЧНИХ ГРУП ДЛЯ ВИКОНАННЯ БАГАТОФУНКЦІОНАЛЬНИХ ЗАВДАНЬ ПІД ЧАС ВЕДЕННЯ БОЙОВИХ ДІЙ
}

У статті проаналізовані проблеми використання малих тактичних груп у сучасних війнах та військових конфліктах як автономних підрозділів для виконання бойових задач у певній обстановці. Проаналізовані варіанти поділу відділення на декілька бойових (тактичних) груп. Склад окремих бойових груп вибирається з урахуванням можливості виконання багатофункціональних завдань. Проведено аналіз методів поділу військових підрозділів за досвідом військових конфліктів $і$ задач, які при иььому вирішувалися. Проведено аналіз наступних методів поділу військових підрозділів на малі тактичні групи: метод комбінованої четвірки, метод розвідувальної n'ятірки, метод 3+4, метод Двійка Пауло. Визначено недоліки та переваги кожного методу. Обгрунтовано, щзо найбільш ефективним методом поділу військових підрозділів при проведенні операцій по боротьбі з терористами є метод Двійка Пауло.

Ключові слова: військовий підрозділ, тактична група, метод розподілу, итурмова група.

\section{Вступ}

Постановка проблеми. Дефіцит свободи ведення бойових дій, ініціативності особового складу у плануванні дій, відсутність постійного всебічного забезпечення за більшістю напрямків, нестача різноманітних засобів бойової підтримки та методів ефективного зв'язку в сучасних умовах протидії 3 боку противника призводить до обмеженого використання механізованого відділення як самостійної бойової одиниці. Однак, використання механізованого відділення як самостійної бойової одиниці містить ряд переваг: збільшує швидкість прийняття рішень (підвищує оперативність управління підрозділом); дозволяє оптимізувати сили та засоби для вирішення окремого тактичного завдання [1-2]. Ці переваги дозволяють підвищити живучість і ефективність механізованих відділень як самостійної бойової одиниці.

Аналіз останніх досліджень і публікацій. У відкритій літературі є джерела, які присвячені дослідженню питань аналізу правил створення та бойового застосування окремих тактичних груп різного призначення [3-7]. Дослідженню перспектив розвитку та бойового застосування сухопутних військ і їх складових підрозділів присвячені роботи [3-4]. В цих роботах визначається, що ядром сухопутних військ армії США в майбутньому стане окрема бригадна тактична група. Такий підрозділ розглядається як “сила безпосередньої дії” тактичного рівня. Відповідно до конкретного призначення всі окремі бригадні тактичні групи поділяють на такі: групи сил спеціальних операцій; піхотний полк "Randger"; повітрянодесантні та легкі піхотні підрозділи; під- розділи перехідного періоду типу "Striker" (із залученням бойових машин піхоти типу “Striker”); “важкі” формування (бронетанкові та механізовані підрозділи); повітряно-штурмові підрозділи. Бригадні групи (бригади) нового типу повинні бути спроможні проводити самостійні бойові дії впродовж кількох діб після прибуття в район оперативного призначення без додаткової підготовки та забезпечення. Характерною рисою перспективних бригад (бригадних груп) $є$ наявність в їх складі необхідного комплекту формувань меншого масштабу різних родів військ в усіх ланках i, як слідство, їх самостійність при вирішенні поставлених завдань [5]. Відмічається, що в результаті реформування на рубежі 20202032 рр. бригади сухопутних військ армії США будуть мати модульну структуру та будуть спроможні діяти як самостійно в звичайному (штатному) форматі, так і у випадку необхідності їх дроблення для автономного проведення підрозділами меншого масштабу тих або інших конкретних акцій, перш за все антитерористичних. Залежно від поставлених завдань модулі різної організації та призначення відділення, секції, взводи, роти, батальйони, зведені в бригадні бойові (а іноді й забезпечуючі) групи будуть передаватися в підпорядкування командирам об'єднаних оперативних формувань для дії за їх планами [5]. Для вирішення завдань проведення розвідувально-пошукових, рейдових, блокувальних дій або штурмових дій, здійснення обходів, охорони важливих об’єктів і комунікацій, супроводження колон, можуть створюватися батальйонні (ротні) тактичні групи [5-6]. Батальйонні тактичні групи створюються у складі механізованого (танкового) батальйону, посиленого танковою (механізованою) 
ротою, артилерійським дивізіоном (батареєю), інженерно-саперною ротою (взводом), розвідувальним взводом та іншими підрозділами. Ротна тактична група складається з механізованої (танкової) роти, посиленої механізованим (танковим) взводом, артилерійським (мінометним) взводом, інженерносаперним відділенням та іншими підрозділами.

У роботах [6-7] проведені системні дослідження, присвячені питанням визначення факторів, які впливають на створення тактичних груп для виконання конкретних бойових завдань. У роботі [6] аналізуються дії тактичних угруповань військ, бригадних, полкових, батальйонних і ротних тактичних груп зі складу оперативних (оперативно-тактичних) угруповань військ уході локальних війн і збройних конфліктів. У роботах [8-11] проведені дослідження щодо оцінювання окремих вогневих показників як стрільців, так і вогневих підрозділів. Недоліком зазначених робіт є те, що бойові підрозділи, які досліджуються, мають значні по кількості сили та засоби. Ці підрозділи діють під чітким керівництвом штабу окремої групи та мають умовну автономність. При появі “нештатних ситуацій” (потрапляння у засідку, втрата зв’язку або підрозділів вогневої підтримки) такі великі бойові групи представляють собою добру мішень для противника. Тому, для підвищення живучості та ефективності військових підрозділів пропонується застосовувати малі тактичні групи. Цьому питанню присвячена дана робота.

Метою статті $є$ дослідження проблемних питань використання малих тактичних груп для виконання багатофункціональних завдань під час ведення бойових дій.

\section{Виклад основного матеріалу}

Вогнева група створена наказом командира нештатне мале бойове формування із 2-3 осіб, що має на меті виконання певного бойового завдання, для якого використання базового виду відділення не є умисним [12-14].

Часто вогневою групою стає гранатометна або кулеметна двійка, що підсилює вогневу міць підрозділу взаємодії. В даному випадку відділення може виконувати завдання як у безпосередньому контакті 3 союзним підрозділом (в його складі на дистанції, що дозволяє пряму взаємодію), так і у вигляді автономної бойової одиниці, що виконує допоміжні цілі.

Наприклад, під час бойових дій в Іраку, коли американські Ренджери використовуючи відносно малі сили - всього в один батальйон, могли охопити велику територію, використовуючи методи дій малих груп (по 3-4 особи), а в умовах повної переваги в засобах підтримки ці відділи могли активно використовувати як вогневу так і авіаційну підтримку через що їх вибиття із міської забудови було неймовірно важким. Наприклад, місто Абас-Катам було захоплене раптовим комбінованим ударом вертольотів вогневих засобів та малими групами піхоти при підтримці двох БТР Scout. Після чого цими ж силами місто утримувалось від військ противника 38 діб. Методом малих вогневих мобільних груп, використовуючи типову доктрину армії США Over support - кругова підтримка. Це передбачає постійне забезпечення навіть найменших підрозділів за більшістю напрямків різноманітними засобами бойової підтримки та методів ефективного зв'язку. Також неймовірно ефективними є спеціалізовані малі групи, наприклад, кулеметні чи гранатометні обслуги відділень.

\section{Метод комбінованої четвірки}

Кулемет + Гранатомет. Комбінована четвірка представляє собою в даному випадку дві обслуги гранатометну або протитанкову (на озброєнні протитанкові ракетні комплекси) та кулеметної обслуги (4 військовослужбовця). Для зручності дій вони виходять на позицію чергування або виконання бойового завдання методами автомобільного транспорту в умовах конфлікту. В Іраку це були замасковані під цивільні позашляховики. Зазвичай вони маскувались під умови ландшафту та дозволяли спорядити підрозділ великою кількістю боєприпасів для забезпечення сприятливих умов виконання завдання. Такий комбінований мобільний, у випадках наділення його автотранспортом, підрозділ здатний забезпечити виконання таких завдань: коротка вогнева засідка проти підрозділів, що не перевищують тактичну вагу роти; стати сегментом маневреної оборони; передислокація підрозділу від однієї вигідної вогневої позиції до іншої на шляху слідування військ противника або на флангах його руху (не даючи йому змогу розширити плацдарм та оперативний простір наступу з затратами мінімальної кількості сил), уповільнюючи його рух та наносячи втрати в живій силі та техніці. Наприклад в Іраку біля Міста Альфаско декілька таких мобільних вогневих підрозділів до восьми четвірок змогли майже тиждень стримувати на відтінку 22 кілометрової лінії маневреної оборони три полки Іракської армії, тобто при співвідношенні 37,5 до одного. Це виняткова ситуація для тактики загалом, оскільки застаріли тактичні принципи говорять, що для успішного наступу необхідна перевага в живій силі та техніці в гіршому випадку 1 до 7. Тому можна сказати, що у таких випадках доктрина малих мобільних груп $є$ надзвичайно ефективною. Американське військове видання AA (American Army) пише про перемоги в умовах Іракської війни таке: “...Американська армія одразу ж в умовах військових дій отримала перевагу і це не та перевага про яку говорять новини та військові ток-шоу це перевага в умінні та ініціативності Американського солдата. Вільність дій та плану- 
вання наступу та відступу усіх кадрів нижчої ланки управління чітке усвідомлення ситуації та розподілу сил в умовах бойових дій усе це приводило до переваги в швидкості прийняття рішень американської армії, подякуємо американським солдатам та їх інструкторам [4]".

Кулемет + стрілецька двійка (або снайперська двійка). Цей вид методики комбінованої четвірки, яка дозволяє більш ефективно відносно минулого випадку використовувати цей підрозділ проти живої сили та малоброньованого автотранспорту противника. Окрім цього даний вид знижує залежність підрозділу від забезпеченості автотранспортом та дозволяє його використовувати в умовах рейдових дій - дуже важлива роль в умовах американської військової доктрини відноситься до так званого неправильного рейду. Ця назва пішла із мемуарів Фрідріха Паульса, що дуже полюбляв традиційну для тактики німецького бліцкригу атаку повітряного десанту рейдом в тил $з$ підсиленням за допомогою танкових військ $з$ фронту. Проте він часто жалівся на десантні підрозділи, що вони замість того, аби постійно маневрувати в тилу ворога, дезорганізуючи його тил, вони, після кількох бойових зіткнень, приймали оборону позицію та в обороні чекали на прорив та підхід танків, після чого продовжували рух як звичайні піхотні підрозділи. Цей феномен він називав неправильним рейдом. I ось саме такий вид дій, коли після короткого за тривалістю рейду (до 40...50 км в глибину ворожого фронту) підрозділи в умовах вигідної географічно тактичної обстановки займають оборону невеликими мобільними відділами або їх сукупністю (що звуться Бойовими групами). Після чого в умовах клаптикового дезорганізованого фронту починається загальний наступ. В таких умовах організувати відступ через осередки противника в тилу сторони, що обороняється, дуже важко. Кількість котлів та мішків збільшується в рази. Дії таких підрозділів на пряму пов'язані з орієнтуванням на місцевості та особистій ініціативності військовослужбовців та офіцерів нижчої ланки. Даний приклад $\epsilon$ в умовах бойових дій в Сирії. Так, за допомогою зрошувальних каналів водопостачання бойові угрупування ІДІЛ не одноразово займали населені пункти в тилу ворожого угрупування, після чого проводили комбінований наступ з фронту та тилу. Наприклад, біля Сирійського поселення Хальмашар таким чином було оточене велике угрупування від 600 до 1200 чоловік військово релігійного угрупування Армія визволення Сирії. Причому майже в два рази меншим угрупуванням ІДІЛ, що знову демонструє перевагу подібних дій в умовах сучасної маневреної війни.

Французький військовий експерт Квентін Ледуа говорив таке: “Ми в дивимось на ІДІЛ як на варварів, не здатних до більшості методів правильного оперативного керування підрозділами. Проте ви бачили їхні тактичні ходи, наскільки сміливі та активні їхні дії в умовах малих підрозділів. Вони геніальні!!!”. У разі, коли замість стрілецької двійки використовується в умовах цього виду методики снайперська двійка, то підвищується ефективність в умовах піхотного зіткнення, сковування дій противника та можливість до ведення бою на далекій дистанції. Проте виникає перевага у вигляді подавлення кулеметним вогнем та враження ворожих вогневих засобів легкого типу снайперським вогнем.

\section{Метод розвідувальної п'ятірки}

Сам метод розвідувальної п'ятірки - був створений як не досконалий спосіб розвідки в умовах існування подібних груп в мало мотивованих арміях світу. Проте поступово від методів розвідки, в умовах присутності офіцеру для контролю, ця модель підрозділу перейняла функцію відділення в умовах короткочасного рейду, а пізніше й взводу, як довгочасного рейду. Зараз такий метод надзвичайно актуальний для проведення стратегії перетікаючих підрозділів, описаний генералом Ле'Клерком в своїх мемуарах. Суть полягає у розбитті взводу на 4 автономних п'ятірки й групи управління та корегування засобів підтримки. Застосовується для розширення лінії маневру підрозділу, як під час розвідки боєм та прощупування оборони противника, або швидкого зайняття територій шляхом максимально швидкого маневру мобільних груп в умовах несформованої або слабкої чи фрагментової лінії оборони. Тому в умовах сучасної Американської доктрини цей метод використання сил є одним з етапів наступу та називається формуванням лінії зіткнення. Наприклад, під час Іракської компанії одна третя територій була окупована після тривалої авіа підготовки майже без боїв швидким напливом малих мобільних груп. Після чого, коли вони почали отримувати опір, з яким такими, відносно малими силами, було важко впоратись, навіть під час наявності ефективної підтримки авіації та артилерії, групи зупинялись та займали мобільну оборону. При цьому:

- малі групи окреслювали лінію зіткнень та територію, що була підконтрольна Американським збройним силам. Це дозволяло перемістити дії авіації та артилерії на вже меншу, не підконтрольну територію;

- мобільні п'ятірки під час фальш наступів та маневрів визначали здатність противника до задіяння резервів підтримки, його числа та оснащення;

- лінія зіткнення, що утворюється таким методом дій піхоти, є неймовірно скривленою, в якій $є$ багато плацдармів та впадин у лінії оборони. Тому, якщо у ворога немає сил, резервів чи можливостей для негайних наступальних дій $з$ метою вирівнювання лінії фронту, то така крива не дозволяє втри- 
мати територію військами оборони у повному обсязі. Зазвичай присутня велика кількість котлів та мішків, що підвищують рівень втрат противника;

- малі групи забезпечували можливість швидкого формування ліній комунікацій через неможливість проникнення через таким чином сформовану в два ешелонна оборону.

Окрім цього, розбиття взводу на вогневі п’ятірки та групу управління збільшує його можливості в умовах маневру вогнем та силами, оскільки, у разі наступу на один осередок військ противника, інші підрозділи можуть передислоковуватись, обтікаючи ворожий кулак, тим самим беручи його у вогневий мішок. Проте в умовах низької професіональності армії ці принципові переваги, як показує практика, не використовуються. Як казав про приклади використання малих відділів у В'єтнамі американський генерал Холіс: “...Ми не можемо спати, ми не можемо їсти. Вороги повсюди. Вони женуться за нами, вони ховаються за кожним деревом, під кожним кущем. Ми мусимо бути постійно на сторожі, бо малі групи ворожих солдатів постійно будуть намагатись проникнути через нашу лінію оборони". Ефективність в даному випадку полягає у тому, що взвод під час спільного маневру входить до спільного похідного порядку. Після прибуття на місцевість проведення бойових дій цей підрозділ розділяється, утворюючи бойовий порядок, визначаючи позиції відділень та пункт управління взводу. У випадку, коли взвод, розбитий на менші автономні підрозділи без формування спільного порядку, до переміщення на малу дистанцію, займає позиції, відбувається наведення комунікації, утворюється так звана біологічна лінія зіткнення. Швидкість та ініціативність дій автономних частин підрозділу в таких випадках набагато більша - отже для сучасної війни подібне використання має явний пріоритет.

\section{Метод 3+4}

Варіант використання того ж піхотного відділення, однак в абсолютно новому варіанті взаємодії, 3'явився ще в умовах конфлікту у В'єтнамі - в умовах частих зіткнень на близьких дистанціях $з$ противником. В'єтнамська армія почала використовувати замість одного відділення у 10 чоловік, що у разі засідки ставали легкою ціллю для розпорошених за укриттями американців, стала використовувати два напіввідділення по 5 чоловік, що рухались на відстані 80-100 метрів один від одного. Отже, якщо на один підрозділ нападав ворог, то він отримував удар іншого підрозділу у фланг чи тил. У разі зіткнення 3 надто великими силами противника інший підрозділ міг відійти не вступаючи в бій. Проблемою тактики солдат північного В'єтнаму було паралельне розміщення на тактичній площині двох спільних підрозділів. Американські солдати в умовах бойових дій доволі швидко доопрацювали таку похибку. Тепер підрозділи рухались не паралельно, а один навскоси випирав вперед над іншим, створюючи косу лінію. Також постало питання, як оптимізувати дану тактику до американського піхотного відділення, що налічувало всього 7 чоловік. Вихід здавався очевидним. Попереду рухався більший підрозділ на відстані від 20 метрів до 50 метрів. Цей підрозділ міг довше сковувати боєм противника, а зміна площини у паралельному векторі робила так, що менший підрозділ, забезпечуючи міцний вогневий контакт, навскоси робив охоплення іншого. В умовах сучасної маневреної війни подібний бойовий порядок відділення широко використовувався у підрозділах американських десантників в умовах тилового рейду. На рівні відділення немає ліпшого методу, ніж метод групової взаємодії Така модульна система на рівні взводу дає вагомі переваги. Так звана коса взаємодія відкриває нові можливості для маневрування підрозділу. Коли передовий підрозділ накривають вогнем, сковують боєм або у подібних фатальних ситуаціях, що діють, в першу чергу на можливість маневру, інший підрозділ в умовах косої взаємодії може, маневруючи, обійти ворога 3 флангу аби не дати можливості вести ефективний вогонь по своїх побратимах. Такі групи підрозділів від 2 до 6 осіб називаються в американській військовій літературі Бойова маневрова група. Така група повинна, не забираючи права автономності прийняття рішень, забезпечити взаємозв'язок між відділеннями та сформувати смугу наступу. Подібні маневри являються надзвичайно ефективними, адже вони забезпечують повне охоплення сил ворога й до найменших аспектів дозволяє вивчити його оборону. Так, наприклад, під час війни в Перській затоці, коли 52 батальйон морської піхоти під час одного з штурмів міста Хулла використав подібний маневр для того, щоб максимально швидко визначити слабкі місця в смузі наступу та здійснити прорив ворожих сил на ділянці фронту з мінімальними силами та можливостями для підведення резервів. Окрім цього цей самий батальйон поніс набагато менші втрати ніж його сусід - 12 батальйон морської піхоти, оскільки подібне розбиття підрозділу на менші частини дозволяє відкрити для відділення як тактичної одиниці нові опції в звичному розумінні тактики. Одне відділення не може взяти інше у вогневий мішок. Для цього потрібно як мінімум два автономних або напівавтономних підрозділи. Ця ж модель поведінки відділення дозволяє розбити його на дві напівавтономні частини. Це дозволяє йому виконувати бойові та тактичні дії. Як казав Марческо Нолліві, італійський полковник, автор мемуарів про війну в Кувейті та Сирії: “...Так, один в полі не воїн, але вогнева трійка чи двійка в сучасній війні - сила $з$ якою можна рахуватись при правильному використанні і на ротному рівні". 


\section{Метод Двійка Пауло}

Двійка Пауло - стандартне розбиття відділення в американській армії, що використовується з метою розвідки або застосування опціональної доктрини мурашника - тобто розбиття більших підрозділів на їх фрагментальні частини в умовах оборони, коли ворог має перевагу в артилерії чи авіації. Розміщення новоутворених підрозділів відбувається за принципом повного вогневого контакту, тобто так, щоб одні вогневі точки перетинались у векторах ефективного вогню з іншими точками. Так званий мурашник приводить до того, що противник не може чітко визначити площину та глибинну оборони i йому доводиться проводити атаки в глибину мурашника, деякі вогневі позиції якого до певного часу можуть затихати. В умовах подібної дезорієнтації різними площинами вогню не можливо відновити знов. Використання ж двійки як автономного диверсійнорейдового підрозділу неможливе, тому доводиться працювати в умовах відстані звуко-вогневого контакту $30 \ldots 70$ метрів. Отже, подібні двійки розгортаються у відносній віддаленості 10 м один від одного, після чого згідно з рухом тилом та флангом ворога, рухаються таким чином, щоб максимально розтягнути свої бойові порядки та створити умови для вогневого мішка або обходу ворога. Ці двійки $є$ дуже ефективними проти навіть не суттєво більших сил противника. Практика нижчої ініціативи в умовах такого методу взаємозв'язку підрозділів визначає командир 3 метою оптимізувати види та фактори тактичних переваг відносно обставин бою. Розглядаючи основні порядки можна виділити:

- шаховий - порядок ключової взаємодії в умоваx перехресного зіткнення 3 противником від чого противник мусить розривати свої порядки або займати позиційну оборону. У другому випадку це призводить до втрати ініціативи в бою та отримання потенційного вогневого охоплення. У випадку міських або боїв в залісеній місцевості призводить до можливості оточення або непомітного зближення на дальність дій стрілецької зброї або звичайного гранатометання. Цей підвид моделі Двійка Пауло призводить до:

1) неможливості використання ворогом у повній ефективності засобів вогневої, артилерійської, та авіаційної підтримки, оскільки здебільше підрозділи противника та автономні тимчасові вогневі позиції двійок знаходяться або в безпосередній близькості до ворога, або розкидані по місцевості, що мінімізуе втрати від концентрованого використання підтримки артилерії та авіації;

2) неможливості використання повних військових підрозділів, використання великих та середніх штурмових груп, штурмових груп для здійснення ліквідацій окремо взятих тимчасових вогневих позицій з причин перехресного вогню в умовах оборони чи маневру;
3) можливості постійного маневрування автономних частин для дезорієнтування розвідки противника;

4) можливості формування шахових квадратів - це спеціальні види маневру автономних двійок 3 можливостями постійного чи фрагментарного зв'язку між собою, що в ході маневру утворюють умовний квадрат вогню між собою. Цей квадрат вогню перетворюється в подальшому в короткий вогневий контакт 3 ворогом 3 чотирьох напрямів, а виходячи $з$ основних можливостей, до реакції ланки співставної з відділенням при звичайному використанні призводить до похибок розгортання бойового порядку. До таких похибок належать: скупчення особового складу; намагання здійснення неправильного прориву; залягання з частковою координацією сил; дезорганізація бойової одиниці. В лінію цей бойовий порядок дозволяє проводити зіткнення 3 противником, використовуючи метод хвиль, тобто поступового проникання в глибину ліній оборони чи просто в бік противника. Після чого противник знищується на короткій дистанції. Це дає можливість:

1) скоротити оперативну площину (в міру цього зменшується можливість до покриття перехресним вогнем, збільшується організованість та штурмові властивості підрозділу). Це дозволяє, визначивши слабкість ворога, швидко зблизитись та в мертвій зоні для вогню ворога здійснити прохід його лінії оборони;

2) послідовно сковувати вогнем противника, приводити до неможливості концентрування вогню на певному підрозділі;

3) в умовах міської забудови таке шикування в міських умовах приводить до можливості визначення прихованих вогневих точок та взаємному забезпеченню вогневим базисом для мінімізації факторів, що сприяють створенню вогневих мішків за рахунок здатності даного підрозділу швидко зорганізувати покриття вогнем живу силу та вогневі засоби противника з різних вогневих площин.

Двійки Пауло - це вихід для використання підрозділів в умовах ворожої вогневої переваги. При цьому, коли кілька підрозділів забезпечують дублювання функцій, використовуючи різні позиції, порядок руху та послідовність дій, противнику важче забезпечити поразку (тобто не виконання певного завдання підрозділом) наших підрозділів.

Практичне використання двійки Пауло відбувалось в умовах війни в Афганістані з боку Талібану, після чого цим біологічним (самовільно створена доктринальна модель малого підрозділу) методом тактичної дії зацікавились американські спеціалісти. Цей метод активно використовується в умовах так званих вовчих груп - шістка трьома двійками в спецназі, та не раз допомагав армійцям у важких умовах урбанізованого бою. В місті неймовірно гарно 
можуть працювати типи та методи використання відділення подібним чином, оскільки вогнева двійка може змінювати позицію, з поверху на поверх, від будівлі до будівлі, тим самим дезорієнтувавши ворога. Стосовно кількості вогневих засобів та особового складу. У разі необхідності перейти у наступ вогневі двійки з легкістю об'єднуються в шістки або вісімки - штурмові групи. Тактика штурмових груп у плані використання поділу відділення на двійки Пауло надзвичайно важлива. Деякі військові спеціалісти навіть не поділяють ці два тактичні методи між собою, а вважають двійку Пауло та методику штурмових груп двома тактичними етапами одної структури використання відділення. Двійковий етап відповідає за ефективний рух та оперативний контроль території противника, дозволяє проникнути зберігаючи умови маскування через важко проходимі для відділення в звичній формі елементи місцевості. Після виконання тактичних задач підрозділ переформатується в штурмову групу в шість - вісім чоловік. Штурмова група у даному розумінні є ма- лим маневреним підрозділом, що завдяки концентрованому шикуванню особового складу бойового підрозділу здатний форсовано знищити ворожий опорно вогневий пункт чи оволодіти певною позицією.

\section{Висновок}

У роботі проведено аналіз проблемних питань використання малих тактичних груп у сучасних війнах та військових конфліктах як автономних підрозділів для виконання бойових задач у певній обстановці. Проаналізовані варіанти поділу відділення на декілька бойових (тактичних) груп. Проведено аналіз наступних методів поділу військових підрозділів на малі тактичні групи: метод комбінованої четвірки, метод розвідувальної п'ятірки, метод $3+4$, метод Двійка Пауло. Визначено недоліки та переваги кожного методу. Обгрунтовано, що найбільш ефективним методом поділу військових підрозділів при проведенні операцій по боротьбі 3 терористами $є$ метод Двійка Пауло.

\section{Список літератури}

1. Поляков С. Ю., Лєнкін В. М., Зміївський Г. А., Шкуропацький О. І. Деякі аспекти удосконалення тактичної підготовки курсантів (студентів) військових підрозділів вищих навчальних закладів. Збірник наукових пращь Харківського начіонального університету Повітряних Сил. 2014. № 1(38). С. 292-298.

2. Дробан О. М., Жохальський Е. Ф. Підходи до оцінки ефективності стрільби зі стрілецької зброї. Військовотехнічний збірник. 2018. № 19. С. 19-23. https://doi.org/10.33577/2312-4458.19.2018.19-23.

3. Ярош С. П., Рогуля О. В. Аналіз тактики бойового застосування крилатих ракет при нанесенні ударів по важливих державних об'єктах та угрупованнях військ. Збірник наукових праџь Харківського національного університету Повітряних Сил. 2019. № 3(61). С. 35-44. https://doi.org/10.30748/zhups.2019.61.06.

4. ADRP 3-0: Unified Land Operations. Washington : Headquarters Department of the Army Washington, 2012.74 p. URL: https://www.lsu.edu/hss/milsci/resources/adrp3_0.pdf (accessed 03.06.2021).

5. Гурін О. М. Проведення аналізу шляхів формування обгрунтованого раціонального варіанту тилового забезпечення бойових дій Повітряних Сил Збройних Сил України. Збірник наукових праць Харківського національного університету Повітряних Сил. 2016. № 1(46). С. 37-40.

6. JP 1-02. Department of Defense Dictionary of Military and Associated Terms. Washington : US Government Printing Office, 2010. 693 p. URL: https://irp.fas.org/doddir/dod/jp1_02.pdf (accessed 03.06.2021).

7. Ярош С. П., Гузченко С. В. Класифікація тактичних груп. Збірник наукових праць Харківського національного університету Повітряних Сил. 2016. № 3(48). С. 21-25.

8. Телелим В. М., Загорка О. М., Стрижевський В. В. Досвід створення та застосування угруповань військ (сил) у локальних війнах і збройних конфліктах другої половини XX та на початку ХХІ століття. Київ : НУОУ, 2012. 336 с.

9. Шмаков О. М. Словник офіцера внутрішніх військ з воєнно-наукових питань. Харків : АВВ МВСУ, 2009. 518 с.

10. Kriukov O., Melnikov R., Bilenko O., Zozulia A., Herasimov S., Borysenko M., Pavlii V. Modeling of the process of the shot based on the numerical solution of the equations of internal ballistics. Eastern-European Journal of Enterprise Technologies. 2019. No. 1(97). P. 40-46. https://doi.org/10.15587/1729-4061.2019.155357.

11. Zhuravlov O. O., Kolomiitsev O. V., Herasymov S. V. Method for determining coefficient power error of front resistance missile by means station outwardly trajectory measurements. Scientific Works of Kharkiv National Air Force University. 2017. Vol. 3(52). P. 72-76.

12. Журавльов О. О., Коломійцев О. В., Герасимов, С. В., Чумак, Б. О. Метод оцінки значення похибки коефіцієнта сили лобового опору снаряда за результатами зовнішньотраєкторних вимірювань. Озброєння та військова техніка. 2017. № 14(2). C. 29-33. https://doi.org/10.34169/2414-0651.2017.2(14).29-33.

13. Герасимов С. В., Журавльов О. О. Оцінка коефіцієнта лобового опору снаряда методами поліноміальної апроксимації та інтерполяції координат центра мас на етапі льотно- конструкторських випробувань. Озброєння та військова техніка. 2017. № 15(3). С. 30-34. https://doi.org/10.34169/2414-0651.2017.3(15).30-34.

14. Блащук С. В., Медінець I. Р. Негативні фактори, які впливають на ефективність використання механізованого відділення під час ведення бойових дій. Новітні технології - для захисту повітряного простору : зб. тез доп. XV наук. конф. курсантів та студентів Харківського національного університету Повітряних Сил ім. І. Кожедуба. Харків : ХНУПС, 2019. С. 68-69.

15. Медінець I. Р., Качан М. В., Блащук С. В. Тактика та методика використання механізованого відділення для виконання мультифункціональних завдань під час ведення бойових дій. Новітні технологіі - для захисту повітряного простору : зб. тез доп. XV наук. конф. Харківського національного університету Повітряних Сил ім. І. Кожедуба. Харків : ХНУПС, 2019. С. 29. 
16. Булай А. М., Василенко В. В., Добровольський Д. Д., Кадубенко В. С., Скопінцев О. О. Оцінка ефективності стрільби зі стрілецької зброї по цілям з індивідуальним броньованим захистом. The scientific heritage. 2020. №. 49. Р. 4.

\section{Відомості про авторів:}

Лук'янов Сергій Миколайович

старший викладач

Харківського національного університету

Повітряних Сил ім. І. Кожедуба,

Харків, Україна

https://orcid.org/0000-0001-8273-3504

\section{Медінець Іван Романович}

старший викладач

Харківського національного університету

Повітряних Сил ім. І. Кожедуба,

Харків, Україна

https://orcid.org/0000-0003-0750-4423

\section{Тітов Олексій Сергійович}

викладач

Харківського національного університету

Повітряних Сил ім. І. Кожедуба,

Харків, Україна

https://orcid.org/0000-0002-9401-6454

\section{Блащук Сергій Вікторович}

курсант

Харківського національного університету

Повітряних Сил ім. І. Кожедуба,

Харків, Україна

https://orcid.org/0000-0003-2388-813X
Information about the authors:

\author{
Serhii Lukianov \\ Senior Lecturer \\ of Ivan Kozhedub Kharkiv National \\ Air Force University, \\ Kharkiv, Ukraine \\ https://orcid.org/0000-0001-8273-3504
}

\author{
Ivan Medinets \\ Senior Lecturer \\ of Ivan Kozhedub Kharkiv National \\ Air Force University, \\ Kharkiv, Ukraine \\ https://orcid.org/0000-0003-0750-4423
}

\author{
Alexey Titov \\ Lecturer \\ of Ivan Kozhedub Kharkiv National \\ Air Force University, \\ Kharkiv, Ukraine \\ https://orcid.org/0000-0002-9401-6454 \\ Sergei Blaschuk \\ Cadet \\ of Ivan Kozhedub Kharkiv \\ National Air Force University, \\ Kharkiv, Ukraine \\ https://orcid.org/0000-0003-2388-813X
}

\title{
АНАЛИЗ ПРОБЛЕМНЫХ ВОПРОСОВ ИСПОЛЬЗОВАНИЯ МАЛЫХ ТАКТИЧЕСКИХ ГРУПП ДЛЯ ВЫПОЛНЕНИЯ МНОГОФУНКЦИОНАЛЬНЫХ ЗАДАЧ ВО ВРЕМЯ ВЕДЕНИЯ БОЕВЫХ ДЕЙСТВИЙ
}

\author{
С.Н. Лукьянов, И.Р. Мединец, А.С. Титов, С.В. Блащук
}

В статье проанализированы проблемы использования малых тактических групп в современных войнах и военных конфликтах как автономных подразделений для выполнения боевых задач в определенной обстановке. Проанализированы варианты разделения отделения на несколько боевых (тактических) групп. Состав отдельных боевых групп выбирается с учетом возможности выполнения функииональных задач. Проведен анализ методов разделения военных подразделений по опыту военных конфликтов и задач, которые при этом решались. Проведен анализ следующих методов разделения военных подразделений на малье тактические группы: метод комбинированной четверки, метод разведывательной пятерки, метод $3+4$, метод Двойка Пауло. Определены недостатки и преимущества каждого метода. Обосновано, что наиболее эффективным методом разделения военных подразделений при проведении операций по борьбе с террористами является метод Двойка Пауло.

Ключевые слова: военное подразделение, тактическая группа, метод распределения, итурмовая группа.

\section{ANALYSIS OF PROBLEM ISSUES OF USING SMALL TACTICAL GROUPS TO PERFORM MULTIFUNCTIONAL TASKS DURING COMBAT}

\author{
S. Lukianov, I. Medinets, A. Titov, S. Blaschuk
}

The article analyzes the problems of using small tactical groups in modern wars and military conflicts as autonomous units to perform combat missions in a particular situation. The aim of the article is to study the problematic issues of using small tactical groups to perform multifunctional tasks during hostilities. Variants of division of the squad (section) into several combat (tactical) groups as well as options for their combat formations and the specifics of actions in certain situations are analyzed. It is also analyzed that the division of the platoon into fire groups and control groups increases its capabilities in terms of fire and force maneuver. In the article figure out that the composition of individual combat groups is selected taking into account the possibility of performing multifunctional tasks and their specifications. An analysis of the methods of division of military units based on the experience of wars, military conflicts, armed internal conflicts and the tasks that were solved. The analysis of the following methods of division of military units into small tactical groups: the method of combined four, the method of reconnaissance five, the method of $3+4$, the method of Paulo Two or in a particular situations in which there is a need to combine several of the previously listed options for the formation of small tactical groups to increase the effectiveness of destroying the enemy or mastering his important positions. The disadvantages and advantages of each method are identified and proved that specialized small groups are incredibly effective during an execution combat tasks or combat orders. It is substantiated that the most effective method of separating military units in conducting operations to combat terrorists is the Paulo Two method that is responsible for the effective movement and operational control of enemy territory.

Keywords: military unit, tactical group, method of distribution, assault group. 